\title{
A Valencian-style Coalition Government: el Botànic*
}

\author{
Rosa Roig \\ UNIVERSITAT DE VALÈNCIA \\ rosa.roiglauv.es \\ ORCID. 0000-0003-2408-8417
}

Received: 07/10/2019

Accepted: 21/02/2020

\begin{abstract}
Coalition governments are common in the European political landscape in various tiers of government. However, such coalitions were an exception in the history of the Valencian Autonomy until 2015, which marked a new stage with the so-called El Botànic governments. Which factors explain this change in the Valencian political system? What are the features of such coalition governments? Can this model be applied to other political systems? This paper addresses these and other issues. First, it looks at what led to coalition governments in both 2015 and 2019 . Second, it studies the model of coalition government. The hypothesis tested is this: El Botànic is a coalition government whose success in terms of stability and governmental action is framed within a specific Valencian political context.
\end{abstract}

Keywords: Governmental coalition, Valencian Region, Coalition politics, Spain of the autonomies, Government formation.

Corresponding author: Rosa Roig. Universitat de València, Facultad de Derecho. C/Professor Francisco Tomás I Valiente, 4, 46022 València (Spain).

Suggested citation: Roig, R. (2020). A Valencian-style Coalition Government: el Botànic. Debats. Journal on Culture, Power and Society, 5, 145-158. DOI: http://doi.org/10.28939/iam.debats-en.2020-8

* Acknowledgements. I wish to briefly thank Prof. Antonio Robles Egea for his comments. Nevertheless, the author assumes full responsibility for the study and any errors it may contain.

This study was conducted within the framework of the research project Flujos de información y efectos conceptuales, mediadores de la innovación económica y social. Nudgets contra la corrupción [Information Flows and Conceptual Effects, Mediators of Economic and Social Innovation. Nuggets Against Corruption] (reference AICO/2019/053). 


\section{THE PATH TOWARDS A COALITION GOVERNMENT}

Ever since the end of the $20^{\text {th }}$ Century, debates have been held in Valencia's Regional Parliament on the need to change the Electoral Act, especially the 5\% threshold to win seats. Revoking this provision would open the way for parties much smaller than the Partido Popular and the Socialists, which alternately held power of over thirty years. Nevertheless, a much wider political spectrum was represented after the 2015 Regional Election despite the Electoral Act remaining unchanged. The political context shifted from a twoparty system to a five-party system with the incorporation of two new parties: Ciudadanos and Podem. The number of choices rose to six in 2019 with the entry of a new party: Vox. The party fragmentation index stood at around 2.5 in 1993 but by 2019, it had reached 5.24 (Table 2). This created a new scenario for the Valencian Regional Government, which had been run by a coalition since 2015 . What were the factors shaping these new interaction dynamics among the parties and that yielded a coalition government? To answer this question, we first look at the judicial and institutional framework. We then go on to analyse the electoral system and the system of Valencian political parties. The ideology of the coalition members is a further aspect that is examined. Last but not least, we focus on the historical context.

Theories on the formation of coalition governments tend to fall under one of two heads: formal theories, and multi-dimensional theories. In general, formal theories are based on rational choice theories and on game theory, in which political parties are seen as simply power machines seeking ministerial posts (Budge and Laver, 1986; Matas, 2015; Reniu, 2010; Strøm, 1985 and 1990). From this standpoint, parties emerge as rational actors that decide to form part a 'minimal winning coalition' - a term coined by Riker (1975) to define those coalitions in which the sum of the parties furnishes an absolute majority of parliamentary seats. As Reniu (2010) noted, this approach to the formation of coalition governments does not explain minority governments, such as the first Botànic one in 2015 (so called because the coalition pact was signed in Valencia's Botanic Garden).
Multi-dimensional theories, as their name suggests, incorporate other variables such as the institutional framework and the party system (among others) to grasp what brings a coalition about. This paper takes the multi-dimensional approach. Specifically, it adapts the analytical approach developed by Prof. Matas (2015) for the study of coalition governments. It identifies three main groups of determining variables in the process, to wit: (1) the judicial and institutional framework; (2) the electoral system and the party system; (3) the ideology of the political parties and the historical context. Taking this approach, we analyse the region's Botànic coalition in connection with the Valencian Autonomous Community's coalition governments since 2015 .

\section{THE JUDICIAL AND INSTITUTIONAL FRAMEWORK}

"The starting point for negotiations is first, the desire to form a coalition government, and second, having sufficient parliamentary support to make such a government work" (Matas, 2015: 25). Depending on the way a parliamentary system works and the election results, political parties express a wish to either form a coalition government or not. From this standpoint, the judicial and institutional framework is a decisive factor in such negotiations.

Under the terms of Valencia's Statute of Autonomy, a candidate must win a parliamentary vote to be invested President of the Valencian Government. He has two opportunities to do so. In the first round, he must win an absolute number of votes in the chamber. If that attempt fails, there is a second chance, in which a simple majority of the votes suffices. That said, running a minority government requires great negotiating skills, given that one needs to reach an understanding with the Opposition either through ad hoc agreements or through one covering the whole legislature. Failure to reach such an agreement runs the risk that the Opposition may block legislation or even bring the government down through a vote of 'No Confidence'. In other words, the quest for an absolute parliamentary majority not only focuses 
Table 1 Valencian Regional Elections: Parliamentary Representation (percentages)

\begin{tabular}{|c|c|c|c|c|c|c|c|c|c|c|}
\hline \multirow{2}{*}{$\begin{array}{l}\text { Electoral } \\
\text { candidacies }\end{array}$} & \multicolumn{10}{|c|}{ Valencian Regional Elections } \\
\hline & 1983 & 1987 & 1991 & 1995 & 1999 & 2003 & 2007 & 2011 & 2015 & 2019 \\
\hline CDS & - & 11.36 & - & - & - & - & - & - & - & - \\
\hline Cs & - & - & - & - & - & - & - & - & 12.66 & 17.45 \\
\hline $\mathrm{CC}$ & - & - & - & - & - & - & - & 7.07 & 18.71 & 16.44 \\
\hline EU & $7.51^{* *}$ & $8.03^{* * * *}$ & 7.6 & 11.7 & 6.15 & 6.45 & 8.13 & 5.8 & -- & - \\
\hline PP & $32.11^{*}$ & $23.96^{* * *}$ & 28.1 & 43.3 & 48.63 & 47.9 & 53.22 & 48.6 & 26.98 & 18.85 \\
\hline Podem & - & - & - & - & - & - & - & - & 11.57 & $7.98^{* * * * *}$ \\
\hline PSPV-PSOE & 51.77 & 41.72 & 43.3 & 34.3 & 34.45 & 36.52 & 35.02 & 27.57 & 20.95 & 23.87 \\
\hline UV & - & 9.24 & 10.5 & - & - & - & - & - & - & - \\
\hline Vox & - & - & - & - & - & - & - & - & - & 10.44 \\
\hline
\end{tabular}

* In this election, the alliance AP-PDP-UL-UV is considered as PP.

** In this EU election, this refers to the PCE-PCPV electoral candidacy.

*** In this election, what today is the PP entered the election as AP.

**** In this EU election, this refers to the EU-UPV electoral alliance.

${ }^{* * * * *}$ In this election, Podem refers to the Unides Podem-EU electoral candidacy.

Source: Corts Valencianes, http://www.cortsvalencianes.es. Author.

on the investiture but also on the political stability of the new government and the ease with which it governs. This is especially important given that law-making requires a minimum of one more than half of all MPs to vote for it. In the case of the Bill to reform the Valencian Electoral Act, first presented years ago, requires the support of at least two thirds of all MPs - a hurdle that has yet to be overcome since none of the proposals to date has commanded sufficient support.

Within this judicial framework, the make-up of the Valencian Parliament following the 2015 and 2019 elections (in which no party had an absolute majority) (Table 1) meant that parties had no option but to form alliances if they wished to govern. It is possible to overcome the hurdle of the investiture of the President with a simple majority (at the second attempt) as noted earlier. Yet a government lacking sufficient parliamentary support will soon run into trouble when it comes to enacting legislation. Getting annual budgets passed is an object lesson in what can go wrong.

Laakso and Taagepera's NEPP formula (1979):1

$$
N=\frac{1}{\sum_{i=1}^{n} p_{i}^{2}}
$$

The rise in the effective number of political parties from 2.16 in 1983 to 5.24 in 2019 reveals a highlyfragmented parliament, leading parliamentary parties

1 The NEPP index measures the effective number of political parties - that is to say, how far the party system is fractured. This formula is attributed to Laakso and Taagepera (1979), who calculated it bearing in mind the electoral support gained by each party and how this is turned into seats. It provides information on the number of parties making up the party system, and their relative weights, $n$ is the number of political parties, $P$ is the electoral support obtained by parties (only valid votes are counted). 
Table 2 Fragmentation Index of the Valencian Party System: NEPP (Number of Effective Political Parties)

\begin{tabular}{l|l|l|l|l|l|l|l|l|l|l|l|}
$\begin{array}{l}\text { Year } \\
\text { marking } \\
\text { start of } \\
\text { legislature }\end{array}$ & 1983 & 1987 & 1991 & 1995 & 1999 & 2003 & 2007 & 2011 & 2015 & \\
\hline NEPP & 2.16 & 3.09 & 2.5 & 2.72 & 2.17 & 2.22 & 2.22 & 2.35 & 4.48 & 5.24 \\
\hline
\end{tabular}

Source: Corts Valencianes, http://www.cortsvalencianes.es. Author

to come up with new behaviour patterns. Among new parliamentary parties such as Ciudadanos, Unides Podem, and Vox, there was a two-fold increase in the weight of the Valencian nationalist parties, which stood in the elections under the joint Compromís platform together with the ecologists (Verds Equo) and the Communists (IPV). This created new dynamics when it came to dialogue and co-operation. It seemed likely that no party could govern without first reaching agreements with other parties. An effort was therefore made to compromise in an attempt to marshal the support needed to govern. In our study, it was the Left-Wing parties that strove most to strike a deal. This was seen in both the investiture of the President of the Valencian Government and in coming up with a political manifesto for implementation by the new government. In effect, the Botànic agreements between Compromís, PSPV-PSOE and Unides Podem-EU constituted a political programme that was to guide the government's actions. The programme's implementation was guaranteed by virtue of the fact that it enjoyed the support of three parliamentary parties which taken together commanded an absolute majority.

This absolution majority played in the decision point - a concept enshrined in the formal theories put forward by Strøm (1985) and which, as Reniu (2010) notes, is very useful in understanding the first step in the process. The decision point refers to the minimum support required for a government or parliamentary Bill to be passed and become an Act. The number of parliamentary votes needed for this purpose depends on the nature of the parliamentary procedure - Or- dinary or Special - in each case. It boils down to the parliamentary support The Executive needs to govern.

Put baldly, the judicial and institutional framework is a determining factor in the formation of a coalition government, whether it concerns investing the President, Cabinet Ministers, or in putting public policies into action. Coalition negotiations are thorny because they cover a wide range of goals. Here one should note that the share of power wielded by each member of the coalition is usually a big bone of contention with top-rank and second-rank posts being hard fought over. As we shall see later on, another factor is the wish to carry out policies that satisfy citizens' interests so that the coalition parties can boost their electoral support.

\section{THE ELECTORAL AND PARTY SYSTEMS}

The electoral system is another element explaining the beginning of negotiations to form a coalition. This mechanism transforms citizens' political preferences in parliamentary seats through the right to vote. This means that the electoral system determines parliament's composition and thus the Valencian party system.

We briefly summarise the Valencian electoral regulations because these have an impact on parties' strategies when it comes to forming coalitions. Martínez Sospedra (1996) noted that the Valencian Electoral Act (LEV) was lifted from Spain's Constitutional Act on the General Electoral System (LOREG), save that 
a seat threshold of 5\% was adopted instead of 3\% in the Spanish legislation. Both Acts sought to create a roughly bi-partisan system to avoid excessive political fragmentation, giving the two major parties the best chances of governing and creating a small Opposition incapable of providing a realistic alternative government (Martínez Sospedra, 2007; Pallarés, 1991; Sartori, 1994). This party system was the fruit of a given combination of the three main planks in any electoral system, namely: the electoral formula; the circumscription; the electoral threshold. Table 3 shows the extent to which the vote was concentrated in the two main parties (Partido Popular, and the Socialists) in both Spain's National Parliament (el Congreso) and Valencia's Regional Parliament (les Corts). It clearly shows the 'imperfect bi-partisanship' of Spain's and Valencia's party system from the 1980s up until 2015.

\section{Table 3 Concentration of the vote in PP and PSOE} parties by percentage

\begin{tabular}{|l|l|l|}
\multicolumn{2}{|c|}{ Combined share of vote (\%): PP+PSOE } \\
\hline \multicolumn{1}{|c|}{ Elections } & $\begin{array}{c}\text { Spanish } \\
\text { Parliament }\end{array}$ & $\begin{array}{c}\text { Valencian } \\
\text { Regional } \\
\text { Parliament }\end{array}$ \\
\hline $1979^{*}$ & 58.8 & - \\
\hline $1983^{* *}$ & 68.64 & 83.88 \\
\hline $1987^{* * *}$ & 57.46 & 65.68 \\
\hline 1991 & 63.68 & 71.4 \\
\hline 1995 & 66.11 & 77.6 \\
\hline 1999 & 68.7 & 83.03 \\
\hline 2003 & 69.12 & 84.42 \\
\hline 2007 & 70.54 & 88.24 \\
\hline 2011 & 65.3 & 76.17 \\
\hline 2015 & 52.07 & 47.83 \\
\hline 2019 & 41.57 & 42.72 \\
\hline
\end{tabular}

* In this election, the UCD is considered as the precursor of today's PP.

** In this election, the AP-PDP-UL-UV alliance is considered as PP.

${ }^{* * *}$ In this election, PP appeared as AP

Source: Corts Valencianes, http://www.cortsvalencianes.es. Ministerio del Interior, http://www.mir.es. Author
The Valencian electoral system introduced the D'Hondt proportional representation formula. Nevertheless, the formula's ability to proportionally reflect votes is blunted by the electoral circumscription and the threshold. By choosing the provincial level for delimiting the circumscription, it gives geographical criteria (the principle on which political representation is based) primacy over demographic criteria (the basis of proportional representation). The Valencian Country is Split into three large circumscriptions that are equivalent to provinces, independently of population size. The Valencian Electoral Act thus gives different values to votes depending on the province in which they are cast (Garrido Mayol et al., 2001; Martín Cubas, 2017). "Just like LOREG, Valencia's LEV over-represents the Conservative vote. Less populous rural areas which are tend to be more Conservative ones - are over-represented" (Roig, 2019: 493). This is true of Castellón province. By contrast, urban and coastal areas, such as Valencia, where Left-Wing parties command most support, are under-represented (Calvet, 2010).

This imbalance in the weight given to votes from different areas of The Valencian Country and the 5\% threshold to gain a seat in parliament (the highest threshold in Spain) set a higher electoral barrier than that found in Spain's parliamentary election, or the election to the Catalan and Basque regional parliaments. The threshold establishes the minimum percentage of votes a party must gain in order to get any parliamentary seats and to form part of the party system. Franch i Ferrer $(1995,1996)$ noted that the $5 \%$ threshold means closing the doors of Valencia's parliament to minority parties such as the Valencian nationalists - the so-called PANE (Partidos de Ambito № Estatal or Non-Spain-wide Parties) - which are present at the regional level. The threshold thus limits pluralism in the parliament and strengthens the weight of the two major parties that operate Spain-wide (termed PAE) (Calvet, 2014). In other words, it creates a regional version of the two-party system found at the Spanish level. 
Table 4 Trends in aggregate electoral volatility

\begin{tabular}{|c|c|c|c|c|c|c|c|c|c|c|c|c|}
\hline Elections & 1987 & 1991 & 1995 & 1999 & 2003 & 2007 & 2011 & 2015 & 2019 & 2019 \\
\hline Volatility & 19,05 & 9,99 & 15,8 & 9,015 & 1,55 & 4,25 & 10,73 & 34,95 & 16,07 & 5,24 \\
\hline
\end{tabular}

Source: Corts Valencianes, http://www.cortsvalencianes.es. Author.

Nevertheless, this political system underwent a radical change in 2015 as part of the fall-out from the Spain's economic and political crisis. Since 2009, these crises had affected Spain in general and The Valencian Country in particular (Méndez Gutiérrez del Valle, 2015). New political parties such as Ciudadanos and Podemos popped up in Spain, and a new electoral coalition - Compromís - appeared in Valencia. Compromís brought together the Valencian nationalists (BNV), the Communists (ICP), and 'The Greens' (Verds Equo) in a coalition that broke the mould with a new message and young, charismatic leaders. The three parties garnered the votes of citizens unhappy with the two big parties that had alternated in office hitherto (Roig, 2017).

After three decades of the two big parties taking turns in government, The Valencian Country shifted towards a six-party system in 2019. Votes were spread to the point where Valencia's present regional parliament has no fewer than six parties whereas in the past it was dominated by the two main parties, with one other much smaller party (Legislatures I, V, VI and VII out of a total of 10 legislatures). Using Laakso and Taagepera's fragmentation index, one can see a rise of over $40 \%$ in the number of parties with parliamentary seats (see Table 2). The effective number of parties rose from 2.35 in 2011 to 4.48 in 2015 . By contrast, the growth in the number of parties between 2015 and 2019 was much less, with just one new party being added to those existing in 2015 (with the indeed rising from 4.48 to 5.24 ).
Pedersen Formula (19790): ${ }^{2}$

$$
V=\frac{1}{2} \sum_{i=1}^{n}\left|P_{i, t}-P_{i, t-1}\right|
$$

The electoral volatility index shows the change in the party system. The shift in voting patterns can be seen in the fact that many voters switched allegiance from the two tradition main parties - PP and PSPV-PSOE - to the new political parties - Cuidadanos, Podem, and the new Compromís coalition. The indicator reveals whether voters as a whole were happy or unhappy with the outcome of the previous election. The shift in votes reveals the punishment citizens meted out to the Socialists and the PP - especially the latter, which had been in government for over thirty years.

2 The aggregate electoral volatility index measures the net percentage of voters who changed their vote between one election and another. A value of 0 inidicates that no party has won or lost votes between two elections. By contrast, a value of 100 shows that all voters cast their votes for a different party. Nobody voted for some of the parties that gained seats previous elections. The index provides information on the size of changes within the system of parties.

The elements in the formula are as follows: $n$ is the number of parties taken into account in the two elections; $P_{i, t}$ refers to the percentage electoral support received by party $\mathrm{i}$ in the elections; $P_{i t}+1$ is the electoral support as a percentage obtained by party $i$ in the following election. One should bear in mind that the differences are expressed in absolute terms. 
From a historical perspective, the volatility index's changes reveal the transformation of the Valencian party system. The initial two-party system began with the Socialists in power and ended up with PP in the saddle. A moderate multi-party system followed the 2015 Regional Election - a pattern that was consolidated in 2019. The greatest voter volatility (around the $35 \%$ mark) was seen in the 2015 election, which revealed both the depth of citizens' distrust of the traditional parties and their willingness to try out new ones. This shift in loyalties led to much greater dispersion of votes, shattering Valencia's old two-party system. In so doing, it mirrored what was happening in the rest of Spain.

While the shift in voting patterns drew a new political map, PP and PSPV-PSOE continued to be the two main parties, albeit now within a much more plural party system. They were still the two biggest parties, each within its own ideological bloc (Right and Left, respectively). The number of seats won by a given party is important when it comes to the role it plays in negotiations to form a coalition government.

\section{IDEOLOGY AND THE HISTORICAL CONTEXT}

The ideological variable also affects the forming of a coalition government. This variable can either attract other parties or repel them during the negotiations. Clearly, its repercussion depends on the need to forge a coalition. If a party wins an absolute majority, it is highly likely that it will choose to govern on its own without asking for the support of other parties. However, this was not the case following the 2015 and 2019 elections in The Valencian Country, where no single party was in a position to form a viable government.

The cumulative volatility index (see Table 4) shows vote dispersal. This dispersion led Valencia's parliamentary parties to negotiate to form a coalition government. Logically, the parties tried to reach agreement with those with which they had the greatest ideological affinity, distinguishing between 'Left' and 'Right'. In the Valencian Parliament emerging from the election, the Left-Wing was made up by Compromís, Podem, and PSPV-PSOE, while the Right-Wing comprised Ciudadanos, PP, and Vox.

From this standpoint, there were various options for opening the negotiations to form a coalition government (see Table 5) based on the electoral results. Both Ciudadanos and PSPV-PSOE appeared as the parties heading a Right-Wing or a Left-Wing coalition, respectively. This was because each had the most seats at its end of the political spectrum. The party that positioned itself closest to the centre had the most chances of reaching agreement and of forming a coalition government (whether a Left-Wing one or a Right-Wing one). In this process, the number of seats won by a party and its negotiating experience and skill also make a difference (Robles Egea, 2004).

In a parliament with 99 seats, 50 seats yields an absolute majority. In this case, the most attractive option was to form a Left-Wing government. That was because it would both enjoy an absolute majority and bring together parties with similar ideologies. None of the other options met the 50-seat criterion. This ruled out a successful Vote of No-Confidence by the par-

Table 5 Possible coalition governments, depending on ideology

\begin{tabular}{|c|c|c|c|c|c|c|}
\hline \multirow[b]{2}{*}{ Elections } & \multicolumn{2}{|l|}{ Left } & \multicolumn{2}{|c|}{ Centre } & \multicolumn{2}{|c|}{ Right } \\
\hline & Parties & Seats & Parties & Seats & Parties & Seats \\
\hline 2015 & PSPV-PSOE+Comp+Podem & 55 & PSPV-PSOE + Cs & 36 & $\mathrm{PP}+\mathrm{Cs}$ & 44 \\
\hline 2019 & PSPV-PSOE+Comp+Podem & 52 & PSPV-PSOE+Cs & 45 & $P P+C s+V o x$ & 47 \\
\hline
\end{tabular}


ties that would find themselves in Opposition, thus ensuring the new Left-Wing government the stability it needed to govern.

As mentioned earlier, the process of forming a coalition government is not limited to deciding who sits in Cabinet. That is because it also covers how the government should act. From this perspective, at the very least the negotiating parties need to agree on the government's legislative programme. This means that the parties must seek points of agreement when drawing up the government's programme. In Robles Egea's words (2000: 47): "The actors try to reach an ideologically more consistent outcome with a view to drawing up future political programmes".

Here, one should recall that a key goal of any political party is to boost its electoral support in the following elections, winning more votes each time round. That is why the party's negotiating position is shaped by its manifesto (since this is the tool used to win over the hearts of the target electorate). The point of departure is one where parties find it easier to find a minimum common denominator with others in drawing up a government programme.

The context in which negotiations are conducted influences the role played by the 'ideology' variable. The 2015 regional and municipal elections marked the beginning of a new political cycle in Spain (Llera, 2015; Orriols and Cordero, 2016). Citizens punished the two big Spanish parties, which had managed the country in the aftermath of the 2008 Financial Crisis. The Socialists lost power in 2011. In 2015, it was the PP's turn to feel the voters' wrath. Voters rejected the PP's response to the crisis, which was to slash Welfare State benefits and raise taxes while bailing out financial institutions. The PP had also been involved in a host of corruption cases, including the Gürtel scandal, in which the Valencian PP party was heavily involved. When the scandal broke, the PP was the governing party in The Valencian Country.

The 2015 Valencian Regional Election thus took place against a background in which voters sought change.
This explains why many who had formerly voted PP or Socialist cast their vote instead for other parties whose discourse was based on the need for change. Furthermore, the leaders of the new parties stressed the need to break with the cosy two-party system that had operated hitherto (López García et al., 2016). Given this setting, one needs to analyse the post-election strategies pursued by Valencia's parliamentary parties (with the exception of PP). All those parties touted the idea of change, highlighting their differences from PP, which had been mired in the corruption that had been rife in Valencia both before and during the Global Financial Crisis (GFC). As a result, the PP was something of a pariah and Ciudadanos, Compromís, Podem, and PSPV-PSOE shunned the idea of governing with a party that had become a byword for sleaze. The PP had been in government for over three decades and 'change' meant kicking this party out of office.

The idea of 'change' became a driving force in the negotiations. The parties were keen to open a new chapter in Valencian politics and that meant eschewing a deal with PP - the party that had been in power in the region for over thirty years. As a result, PP was left on the sidelines in the efforts to form a coalition. Furthermore, given the anger many voters felt towards the PP, there was little political incentive to have any truck with it. The Socialists opened the negotiations yet played their hand with a certain ambiguity. Given that the Socialist Party was a Centre-Left one, it could entertain the idea of partners on the Right (such as Ciudadanos), or on the Left (such as Compromís and Podem). The Socialists quickly realised that their party should stick to the Left. That was because this option not only delivered the absolute majority needed to form a stable government but also drew on ideological affinities when it came to Social Policies, Education, and Health. The fact that this first step was taken by PSPV-PSOE made the party the key player in the coalition. The reward was that the Socialists bagged the presidency.

Compromís, despite initially being rejected as a coalition partners, was keen to form part of the government, not least because the party had never been 
in The Executive. Podem, by contrast, took a rather stand-offish position, which only changed after the 2019 elections. Podem initially sought a new LeftWing Valencian Government but without occupying Cabinet posts. The party's support for change was in parliament and through its signing of the 'Botànic' Agreement (which got its name from the fact it was signed in Valencia's Botanical Garden). Yet the party did not occupy government posts. In the 2015 'Botànic' Agreement and its later versions - including the 2019 one - Podem explicitly supported the coalition government's programme covering public policies.

The consensus on the policy guidelines the new government should follow also helped in reaching agreement on how power should be shared out among the parties. Here, one should recall that during the election campaign, Compromís and Podem presented themselves as agents of change. To do so, they highlighted their differences with the Socialists and distanced their parties from PSPV-PSOE and its discourses. Nevertheless, the agreement on ideological points fostered a climate of trust and eagerness. Both the two new Left-Wing parties and their voters were keen to changing the face of Valencian politics. This commitment overcame their reservations about working with one of Spain's two traditional parties. A blended approach (something that was fairly new in coalition power-sharing arrangements) was introduced as a further trust-building measure.

\section{BLENDING}

The coalition government arising from the Botànic Agreement was not only based on negotiations but also on internal arrangements. One of its unusual features was the power-sharing mechanism in both Cabinet and other parts of the government. As in any coalition, each party sought to maximise its share of power. However, the mechanism chosen was a fairly new one: blending. This method had been applied for the first time in a coalition government between Socialists and nationalists in Galicia's Regional Government in 2005. However, it proved something of a failure in Galicia, and PP regained power in the next regional election and has held it ever since. One of the problems in Galicia was the lack of co-ordination among the coalition partners, leading to a loss of public confidence and a feeble government. The approach was abandoned by regional governments until it was taken up anew in The Valencian Country following the 2015 election.

The blending approach incorporated a special formula for sharing political posts among the partners and extended to the second tier of The Executive, which is to say: Deputy Secretaries, Regional Secretaries, and Directorates-General. Under these arrangements, the Regional Secretary working under each Minister would be chosen by another party. The idea was to ensure that departments did not become party fiefdoms and thus a source of friction among the coalition partners. In theory, this would lead to a more cohesive Executive and a system of checks and balances within the Government.

Yet at the beginning of the first Botànic Agreement, this arrangement led to personal clashes in some fields, such as those between The President's Office and the Economics Ministry. As a result, power-sharing was ditched in this particular case and the President ended up holding the reins, with the Socialists appointing all the staff in the President's Office. Meanwhile, Compromís ran the Vice-President's Office and the Ministry for Equality and Inclusive Policies, under Mónica Oltra, save in the case of the DirectorateGeneral for Women, which was run by PSPV-PSOE. The ring-fencing of the President's Office and the Vice-President's Office from the general power-sharing arrangement was repeated in the second edition of the Botànic Agreement after the 2019 Regional Election, marked by the entry of Unides Podem-EU in the coalition. This means that all the staff in the Second Vice-President's Office and in the Ministry of Housing and Bio-climatic Architecture are chosen by the post-holder, Martínez Dalmau.

The power-sharing model sets Valencia's government apart from other Spanish coalitions. It requires a 
Table 6 Distribution of power in the Valencian Regional Government

\begin{tabular}{|c|c|c|c|c|c|c|c|c|c|c|c|c|}
\hline \multirow[b]{3}{*}{ Year } & \multicolumn{4}{|c|}{ Compromís } & \multicolumn{4}{|c|}{ Unides Podem-EU } & \multicolumn{4}{|c|}{ PSPV-PSOE } \\
\hline & \multicolumn{2}{|c|}{$\begin{array}{l}\text { Number } \\
\text { of seats }\end{array}$} & \multicolumn{2}{|c|}{$\begin{array}{c}\text { Cabinet } \\
\text { participation }\end{array}$} & \multicolumn{2}{|c|}{$\begin{array}{l}\text { Number } \\
\text { of seats }\end{array}$} & \multicolumn{2}{|c|}{$\begin{array}{c}\text { Cabinet } \\
\text { participation }\end{array}$} & \multicolumn{2}{|c|}{$\begin{array}{l}\text { Number } \\
\text { of seats }\end{array}$} & \multicolumn{2}{|c|}{$\begin{array}{c}\text { Cabinet } \\
\text { participation }\end{array}$} \\
\hline & Seats & $\begin{array}{l}\text { Seats in } \\
\text { Cabinet }\end{array}$ & $\begin{array}{l}\text { Executive } \\
\text { Members }\end{array}$ & $\begin{array}{l}\text { Executive } \\
\text { weight }\end{array}$ & Seats & $\begin{array}{l}\text { Seats in } \\
\text { Cabinet }\end{array}$ & $\begin{array}{l}\text { Executive } \\
\text { Members }\end{array}$ & $\begin{array}{l}\text { Executive } \\
\text { weight }\end{array}$ & Seats & $\begin{array}{l}\text { Seats in } \\
\text { Cabinet }\end{array}$ & $\begin{array}{l}\text { Executive } \\
\text { Members }\end{array}$ & $\begin{array}{l}\text { Exe- } \\
\text { cutive } \\
\text { weight }\end{array}$ \\
\hline 2015 & 19 & $34.54 \%$ & 5 & $50 \%$ & 13 & $23.63 \%$ & 0 & $0 \%$ & 23 & $41.81 \%$ & 5 & $50 \%$ \\
\hline 2019 & 17 & $32.69 \%$ & 4 & $33.33 \%$ & 8 & $15.38 \%$ & 2 & $16.67 \%$ & 27 & $51.92 \%$ & 6 & $50 \%$ \\
\hline
\end{tabular}

Source: Corts Valencianes, http://www.cortsvalencianes.es, y Generalitat, http://www.gva.es. Author.

Minister to include staff from other coalition parties. These staff members are thus in a position to monitor the government's activities from within. The model is based on dialogue, negotiation, and transparency among the coalition partners at all times and before the citizenry. Co-ordination among the parties is vital in constructing the government spokesman's discourse. At the same time, this approach gives rise to a much more democratic approach to politics from the institutional standpoint.

Podem (one of the parties signing the Botànic Agreement in 2015) decided not to enter the coalition government and instead opted to offer its parliamentary support for the government's programme and power-sharing arrangements. Thus negotiations on forming a coalition government after the 2015 election involved just two parties. By contrast, after the 2019 election, there were three. Unides Podem-EU's decision to form part of the government in 2019 added another actor to the scene and more complex power-sharing arrangements. The political map following the 2019 election changed with: (1) the addition of another coalition partner in the second Botànic Agreement; (2) the fact that the votes won by the Socialists had risen while those won by Compromís and Unides Podem-EU had fallen. The changed political scene led to a new interpretation of the 'blending' approach to power-sharing. First, the mechanism no longer only excluded the President's and the two Vice-Presidents' Offices but was also extended to the Ministry for
Participation, Transparency, Co-operation and Democratic Quality, now in the hands of Unides Podem-EU. Second, Unides Podem-EU staff were not incorporated in those ministries that their politicians did not lead. The 'blending' in this case was thus much more limited in scope. It was only applied in seven out of the eleven ministries and here one should bear in mind that two of those were off limits because they were led by the Vice-President and Deputy Vice-President. Furthermore, the blending arrangements only affected Compromís and PSPV-PSOE staff, given that Unides Podem-EU was left out of the mechanism.

An analysis of the Government's make-up reveals the importance of the co-operation prevailing during the formation of the 2015 coalition. Generosity and trust were key success factors in forming the government. The two coalition partners agreed to share their power equally when it came to Ministries. Here, the Presidency went to the party that had won the most votes. Meanwhile, the Vice-President/Spokesman's Office, and the Ministry for Equality and Inclusive Policies went to the other party. The Executive comprised the nine Ministries and the Presidency. Five were held by Compromís and the other five by PSPV-PSOE. This equal share-out did not take account of the votes won by each political party. In the second-tier of Government posts, power was shared in accordance with the 'blending' formula described earlier. By contrast, in 2019 each party's presence in the Government reflected the number of parliamentary seats it had (see Table 6). 
The reading of the data shown in Table 6 indicates that to form a coalition government through the second Botànic Agreement, all three parties had to be generous with their partners when it came to powersharing. The Socialists decided to put themselves on the same footing as the Valencian nationalists when it came to forming a government, even though they had more parliamentary seats. In 2019, PSPV-PSOE showed the same negotiating skill in incorporating a third party into the coalition. The 2019 negotiations were trilateral instead of bilateral. Power now had to be shared out among three parties, making reaching agreement that much harder. The Valencian nationalists' unwillingness to lose political ground in the government by giving in to Podem's demands to be put on an equal footing with Compromís was a hurdle to signing a second Botànic Agreement. Squaring the parties' diverse interests proved tricky. Indeed, right up until the day of the investiture debate, there was still no agreement on sharing out the Ministries and Vice-Presidencies. A last-minute meeting of the three leaders finally broke the logjam. Settling on the government's organisational structure was also hard. It was solved by boosting staff members - something that was at odds with the austerity message of the first Botànic Agreement but that gave each of the coalition parties what it wanted. On the one hand, compared with 2015 , there was a jump from 9 to 11 ministries, affecting the Valencian Government's overall structure. The number of Under-Secretaries rose from 10 to 11 . The 22 Regional Secretaries rose to 29. Meanwhile, the number of Directorates-General leapt from 56 to 85 . The biggest leap of all was in the number of advisors, which rose to 116 . Here, one should note that there were 'just' 70 advisors in the previous legislature, a little below the maximum of 74 established by the Government Decree 185/2015 of the $16^{\text {th }}$ of October. This naturally begged questions as to whether there was proper control over staffing levels. In percentage terms, both the nationalists and the Socialists made concessions. The Socialists, who had gained four more seats in the 2019 election, kept the same share of power as in 2015. Meanwhile, the nationalists (who had lost three seats) had to give up a ministry to Unides Podem-EU. This was despite the fact that the latter party had lost five seats in the 2019 election. The expansion of political posts gave the Socialists one more Minister and thus the same political weight as the nationalists in absolute terms, thanks to the rise in the number of Regional Secretaries and Directorates-General. Unides PodemEU came away with two Ministries, one of which was headed by the Second Vice-President. To sum up, the formation of a coalition government is only possible if the outcome of the political horse-trading satisfies all parties both at the top tier and second tiers of government.

There were basically three factors making such an arrangement possible. The first was that the Socialists had been out of power in The Valencian Country since 1995 and had lost all the Regional Elections ever since. Regaining the Presidency gave the party a boost and the chance to show that it was capable of governing. The second was that Compromís had never been in government and lacked the electoral muscle needed to get in by itself. The coalition offered Compromís a golden opportunity to step on to the regional stage (hitherto, it had been confined to the municipal realm). Third, the pact between the parties was not limited to the Regional Government but also involved agreements to govern together at the municipal level. Here, the broader goal was to offer a viable political alternative to the Right-Wing. Valencian nationalists and Socialists reached agreements in those town councils where they had a good chance of governing. The pact involved lending each other mutual support and for the party winning the most votes to choose the Mayor. An effort was made to extend the Botànic model to the local sphere, election results permitting. That said, there are always exceptions. Thus, while the Socialists held the Valencian Government presidency with Ximo Puig, in The City of Valencia, it was the nationalists who held the Mayor's Office with Joan Ribó. Running Valencia's City Hall highlighted Compromís' role and made the party happy with the outcome of the negotiations (Barón, 1991; Laver and Schofeld, 1991). 


\section{FINAL REFLECTIONS}

The Valencian coalition model based on the Botànic Agreement came to fruition because the election results drove the parties to strike a deal. This logic stemmed from political fragmentation. First, it was not only parliamentary arithmetic that drove efforts to form a coalition but also a strong wish to push through a political programme. This goal could only be achieved with an absolute majority. Second, the ideological affinity among the parties made it that much easier to draw up a government programme. Third, aware of the need for power-sharing arrangements that kept all sides happy, three new posts were created to ensure each party got a chance to shine.
These posts were: The President's Office, and the two Vice-President's Offices. Each party needed its 'pay-off', namely: (a) the chance to incorporate its proposals in government policies; (b) holding both first-tier and second-tier posts government posts (in addition to having its own bevy of advisors). Fourth, the parties showed a conciliatory streak during the constant negotiations on both the government's legislative programme and on how political posts would be shared out. It was a regional coalition government that sprang from: a desire for change; the aftermath of the 2008 Financial Crisis; citizens' wrath at the PP's corruption spree during its three-decade long spell in government.

\section{ANNEX 1}

\section{Table 7 Political party acronyms}

\begin{tabular}{|l|l|}
\hline \multicolumn{1}{|c}{ ACRONYM } & Alianza Popular \\
\hline AP & Coalició Compromís pel País Valencià \\
\hline CC & Bloc Nacionalista Valencià \\
\hline BNV & Centro Democrático y Social \\
\hline CDS & Ciudadanos \\
\hline CS & Iniciativa de Poble Valencià \\
\hline IPV & Esquerra Unida \\
\hline EU & Partido Comunista de España \\
\hline PCE & Partido Demócrata Popular \\
\hline PDP & Podem \\
\hline PODEM & Partido Popular \\
\hline PP & Partit Socialista del País Valencià - \\
\hline PSPV-PSOE & Partido Socialista Obrero Español \\
\hline UL & Unión Liberal \\
\hline Unides Podem-EU & Unides Podem-Esquerra Unida \\
\hline UPV & Unitat del Poble Valencià \\
\hline UV & Unió Valenciana \\
\hline Verds Equo & \\
\hline
\end{tabular}




\section{BIBLIOGRAPHIC REFERENCES}

Barón, D. P. (1991). A Spatial Bargaining Theory of Government Formation in a Parliamentary System. American Political Science Review, 85, 137-164. doi: 10.2307/1962882

Budge, I. and Laver, M. (1986). Office Seeking and Policy Pursuit in Coalition Theory. Legislative Studies Quarterly, 11(4), 485-506.

Calvet Crespo, J. (2014). Los gobiernos de coalición en la Comunidad Valenciana. In J. M. Reniu (ed.), Los gobiernos de coalición en las comunidades autónomas españolas (p. 361-379). Barcelona: Atelier.

Calvet Crespo, J. (2010). El sistema electoral de les Corts Valencianes: Orígens i reforma. Corts. Anuari de Derecho Parlamentario, 23, 225-256.

Franch i Ferrer, V. (1996). Las elecciones del cambio: Las autonómicas y municipales del 28 de mayo de 1995. Revista Valenciana d'Estudis Autonòmics, 15, 101-262.

Franch i Ferrer, V. (1995). Las elecciones autonómicas valencianas en perspectiva (1983-1991): Los efectos de la cláusula de la barrera del 5\% en el sistema de partidos valenciano. Cuadernos Constitucionales de la Cátedra Fadrique Furió Ceriol, 9/10, 87-113.

Garrido Mayol, V., Martín Cubas, J. and Sóler Sánchez, M. (2001). El nacimiento del Estatuto Valenciano. Valencia: Fundación Profesor Manuel Broseta.

Laakso, M. and Taagepera, R. (1979). "Efective" Number of Parties: A Measure with Application to West Europe. Comparative Political Studies, 12(1), 3-27.

Laver, M. and Schofeld, N. (1991). Multiparty Government: The Politics of Coalition in Europe. New York: Oxford University Press.

Llera, F. (2015). Victoria popular y realineamiento en las elecciones locales, autonómicas, insulares y forales 2015. Sistema, 240, 3-34.

López García, G., Cano Orón, L. and Argilés Martínez, L. (2016). Circulación de los mensajes y establecimiento de la agenda en Twitter: El caso de las elecciones autonómicas de 2015 en la Comunidad Valenciana. Trípodos, $39,163-183$.

Matas, J. (2015). La formación de un gobierno de coalición. Valencia: Tirant Lo Blanch.

Martín Cubas, J. (2016). El Estatuto de Autonomía como marco normativo de una reforma del sistema electoral de les Corts Valencianes. Drets. Revista Valenciana de Reformes Democràtiques, 1, 99-129.

Martínez Sospedra, M. (2007). Sobre la necesidad de una ley electoral valenciana. Corts. Anuari de Derecho Parlamentario, $18,121-145$.

Martínez Sospedra, M. (1996). Participación Política, Autonomía y Ley Electoral. La Ley Electoral Valenciana. Corts: Anuario de Derecho Parlamentario, 2, 15-50.

Méndez Gutiérrez del Valle, R. (2015). Atlas de la crisis. Valencia: Tirant Lo Blanch.

Orriols, L. and Cordero, G. (2016). The Breakdown of the Spanish Two-party System: The Upsurge of Podemos and Ciudadanos in the 2015 General Election. South European Society and Politics, 21(4), 469-492. doi: 10.1080/13608746.2016.1198454

Pallarés, F. (1991). Estado autonómico y sistema de partidos: Una aproximación electoral. Revista de Estudios Políticos, $71,281-323$.

Pedersen, M. N. (1979). The Dynamics of European Party Systems: Changing Patterns of Electoral Volatility. European Journal of Political Research, 7, 1-26.

Reniu, J. M. (2010). Els governs de coalició. Barcelona: Universitat Oberta de Catalunya.

Riker, W. H. (1975). The Theory of Political Coalitions. New Haven: Yale University Press.

Robles Egea, A. (2004). Negociaciones, payoffs y estabilidad de los gobiernos de coalición. Revista de Estudios Políticos, 126, 91-112.

Robles Egea, A. (2000). El estudio de las coaliciones políticas. In J. Matas (ed.), Coaliciones políticas y gobernabilidad (p. 21-57). Barcelona: Institut de Ciències Polítiques i Socials.

Roig, R. (2019). Del bipartidismo al pentapartidismo: Nueva dinámica ideológica. In Una vida dedicada al Parlamento: Estudios en Homenaje a Lluís Aguiló i Lúcia (p. 491-508). Valencia: Corts Valencianes.

Roig, R. (2017). Dinámica ideológica en el ámbito local. Gobiernos de coalición. Estudio de caso: Alicante, Castellón y Valencia. Corts: Anuario de Derecho Parlamentario, 29, 397-426. 
Sartori, G. (1994). Ingeniería constitucional comparada: una investigación de estructuras, incentivos y resultados. Mexico City: Fondo de Cultura Económica.

Strøm, K. (1990). A Behavioral Theory of Competitive Political Parties. American Journal of Political Science, 34(2), $565-598$

Strøm, K. (1985). Governi di minoranza e democrazie parlamentari. Rivista Italiana de Scienza Politica, 15, 167-204

\section{BIOGRAPHICAL NOTE}

Rosa Roig has a PhD in Politics, is Associate Professor at Universitat de València (UV), and is a member of IUED at UV and of the ECPR Steering Committee on Gender and Politics. She is a Visiting Researcher at University of Kent, at Instituto Universitário de Lisboa, and Johannes Gutenberg-Universität Mainz. Roig is a member of sundry R\&D projects, including: EUROPUB; GIPEyOP; Judicial and Sociological Analysis of the Gender Rifts in Work-RetirementWork Transitions. 